\title{
POLA PEMBINAAN UMKM USAHA PENGOLAHAN IKAN KERING DI KELURAHAN PONJALAE TAPONG KECAMATAN WARA KOTA PALOPO
}

\author{
I Ketut Patra ${ }^{1}$, Nurlinda Sabani ${ }^{2}$ \\ Sekolah Tinggi Ilmu Ekonoomi Muhammadiyah Palopo \\ ${ }^{1}$ E_Mail: ketutpatra@stiem.ac.id
}

\begin{abstract}
Abstrak: Usaha perikanan tangkap di Kota Palopo merupakan salah satu usaha agribisnis di Provinsi Sulawesi Selatan. Kondisi geografis Provinsi Sulawesi Selatan yang terletak di sepanjang pesisir selatan pulau Sulawesi dan Teluk Bone sangat mendukung ketersediaan sumberdaya hasil laut yang melimpah. Guna peningkatan nilai tambah dan pemanfaatan hasil laut yang berlimpah, terutama untuk ikan-ikan yang bernilai ekonomi rendah jika dijual dalam bentuk segar, maka upaya pengawetan dengan cara pengeringan sangat strategis.

Pengolahan ikan kering di Kota Palopo dilakukan secara tradisional dengan memanfaatkan energi matahari. Ikan segar dibeli secara curah dengan jenis keragaman yang bervariasi tergantung dengan musim, selanjutnya ikan dibersihkan, diberi garam, dan dikeringkan di atas para-para yang telah tersedia dalam waktu sekitar 8-10 jam per proses produksi. Ikan kering tersedia sepanjang waktu, namun jenisnya bervariasi.

Usaha pengolahan ikan kering di Kota Palopo sangat berprospek untuk dikembangkan, berdasark an hasil analisis model pembiayaan yang telah dilaksanakan diketahui bahwa usaha pengolahan ikan kering ini layak untuk dikembangkan. Analisis keuangan dan kelayakan proyek usaha pengolahan ikan kering sesuai asumsi yang digunakan adalah layak untuk dilaksanakan dengan nilai NPV Rp 6.062.902,923, IRR 1,23\%, Net B/C 3,001, dan PBP 28,9 bulan atau 2,4 tahun. Industri ini juga mampu melunasi kewajiban angsuran kredit kepada bank. Selain itu industri ikan kering ini juga sangat tahan terhadap kenaikan biaya variabel maupun penurunan pendapatan, karena usaha ini masih diang gap layak walaupun kenaikan biaya variabel atau penurunan pendapatan terjadi sampai $10 \%$.

Secara umum dapat disampaikan bahwa industri ikan kering mempunyai peranan penting dalam rangka memenuhi kebutuhan sumber protein dan lemak yang berharga murah bagi masyarakat. Perkembangan usaha perikanan tangkap merupakan faktor pendukung terbesar bagi usaha pengolahan ikan kering agar dapat memasok ikan segar sebagai bahan baku usaha pengolahan dengan harga yang murah dan bermutu tinggi.

Dua faktor terpenting bagi keberhasilan usaha pengolahan ikan kering selain faktor bahan baku adalah tingkat kekeringan dan kualitas pengemasan produk. Tingkat kekeringan akan menjadi faktor pembeda suatu produsen dengan produsen lainnya, dimana akan timbul keterikatan antara konsumen dengan produsen ikan kering tertentu.
\end{abstract}

Keyword: Ikan Kering, Pengolahan Ikan, Kelompok Nelayan, Ikan Asin

\section{PENDAHULUAN}

Sektor perikanan sebagai salah satu pendukung sektor ekonomi memiliki peran dalam pembangunan ekonomi nasional, yaitu memberikan nilai tambah dan mempunyai nilai strategis, serta dapat memberikan manfaat finansial maupun ekonomi, khususnya dalam penyediaan bahan pangan protein, perolehan devisa, dan penyediaan lapangan kerja. Sejauh ini, pembangunan perikanan yang dilakukan telah menunjukkan hasil yang nyata dan positif terhadap pembangunan nasional. Hal ini terlihat dari sumbangan Produk Domestik Bruto (PDB) sektor perikanan terhadap PDB Nasional yang terus meningkat. Kontribusi sektor perikanan dan kelautan terhadap PDB Nasional mencapai sekitar $12,4 \%$. Bahkan industri perikanan menyerap lebih dari 16 juta tenaga kerja secara langsung. (Dahuri, 2004). Ikan asin merupakan bahan makanan yang terbuat dari daging ikan yang diawetkan dengan menambahkan banyak garam. Dengan metode pengawetan ini daging ikan yang biasanya membusuk dalam waktu singkat dapat disimpan di 
suhu kamar untuk jangka waktu berbulan-bulan, walaupun biasanya harus ditutup rapat. Ikan sebagai bahan makanan yang mengandung protein tinggi dan mengandung asam amino essensial yang diperlukan oleh tubuh, disamping itu nilai biologisnya mencapai 90\%, dengan jaringan pengikat sedikit sehingga mudah dicerna oleh konsumen (Adawyah, 2007). Dengan demikian prinsip pembuatan olahan ikan asin merupakan salah satu cara untuk memperpanjang daya simpan dan menambah nilai jual dari poduk tersebut. Sehingga hal ini sangat penting diketahui bagi kita terutama seorang praktikan jurusan perikanan sebagai seorang akademisi dan merupakan ranah bidang ilmu pengetahuan kita. Cara pengawetan ini merupakan usaha yang paling mudah dalam menyelamatkan hasil tangkapan nelayan. Dengan penggaraman proses pembusukan dapat dihambat sehingga ikan dapat disimpan lebih lama. Penggunaan garam sebagai bahan pengawet terutama diandalkan pada kemampuannya menghambat pertumbuhan bakteri dan kegiatan enzim penyebab pembusukan ikan yang terdapat dalam tubuh ikan (Afrianto dan Liviawaty, 1989).

Kota Palopo di Provinsi Sulawesi Selatan terletak pada $02^{\circ} 53^{\prime} 15^{\prime \prime}$ - $03^{\circ} 04^{\prime} 08^{\prime \prime}$ LS dan $120^{\circ} 03^{\prime} 10^{\prime \prime}$ - $120^{\circ} 14^{\prime} 34^{\prime \prime}$ BT dengan batas administratif sebelah utarakecamatan Walenrang berbatasan langsung dengan dengan Kabupaten Luwu, di sebelah selatan terbentang teluk Bone, di sebelah barat berbatasan dengan Kecamatan Tondon nanggala Kabupaten Tana Toraja dan di sebelah Timur berbatasan dengan kecamatan Bua kabupaten Luwu.

Letak strategis Kota Palopo di garis pantai Sulawesi selatan dan menghadap ke teluk Bone berdampak positif pada daerah ini, yaitu memiliki potensi ekonomi yang cukup besar di sektor perikanan. Palopo memiliki potensi perairan dengan 295 jenis ikan karang dan berbagai jenis ikan konsumsi yang bernilai ekonomis tinggi seperti kerapu (Epinephelus spp.), cakalang (Katsuwonus spp.), napoleon wrasse (Cheilinus undulatus), dan baronang (Siganussp.) Sebanyak 244 jenis moluska diantaranya lola (Trochus niloticus), kerang kepala kambing (Cassis cornuta), triton (Charonia tritonis), batulaga (Turbo spp.), kima sisik (Tridacna squamosa), kerang mutiara (Pinctada spp.), dan nautilus berongga (Nautilus pompillius). Jenis ikan tangkapan di wilayah perairan kota sangat beragam, antara lain jenis pelagis besar dan kecil, demersal, dan biota laut lainnya dengan keragaman jenis ikan dan biota laut lainnya. Dalam bentuk segar produk hasil perairan tangkap Kota Palopo memasuki pasar ekspor, yaitu untuk komoditi tuna, cakalang, bawal, kerapu, kakap, udang putih, udang windu, lobster, dan teripang. Sedangkan untuk pasaran lokal dan regional, meliputi komoditi ikan tongkol, tenggiri, cucut, gurita, udang dogol, layur, cumi-cumi, dan lainlain.

Produksi total hasil perikanan tangkap pada tahun 2011 adalah sebesar 29001,5 ton, atau sebesar $36,22 \%$ dari potensi lestarinya. Rata-rata $68 \%$ dari total perikanan Kota Palopo bernilai ekonomis, sisanya sekitar $32 \%$ adalah ikan non ekonomis. Sebanyak $90 \%$ dari total produk ekonomis tersebut dipasarkan ke luar daerah maupun ekspor, sisanya untuk konsumsi lokal. Pemanfaatan ikan non ekonomis dengan rata-rata sebanyak $32 \%$ dari total produksi adalah sebagian 
kecil dikonsumsi segar dan sebagian besar lainnya diolah menjadi ikan kering/asin sebagai upaya pengawetan sehingga dapat dijadikan komoditi andalan daerah. Jenis olahan lainnya yang saat ini mulai dikembangkan adalah tepung ikan.

Ikan kering/asin sebagai produk olahan hasil perikanan di Kota Palopo pada umumnya menggunakan ikan-ikan non ekonomis. Usaha pengolahan ikan kering/asin ini berkembang dengan baik di wilayah-wilayah pesisir pantai Kota Palopo. Kelurahan Ponjalae dan Tapong Kecamatan Wara Kota Palopo merupakan sentra produksi terbesar. Letak wilayah ini tepatnya adalah di sekeliling Pelabuhan Tanjung Ringgit. Letak kampung pengolahan ikan kering/asin ini sangat dekat dengan dermaga pendaratan kapal dan Tempat Pelelangan Ikan (TPI), sehingga kemudahan akses untuk ketersediaan bahan baku sangat terjamin.

\section{METODE DAN BAHAN}

Metode Pelaksanaan program KKN-PPM dalam kegiatan pola pemberdayaan UMKM pengolahan Ikan kering di Kelurahan Ponjalae dan Kelurahan Tapong Kecamatan Wara ini berupa pelatihan dan pendampingan pada aspek teknis penatalaksanaan pembuatan ikan kering dengan beberapa metode baru yang aman, higienis dan jauh dari zat kimia berbahaya. Adapun tahapantahapannya adalah:

Metode yang akan dilakukan dalam pelaksanaan program KKN-PPM ini adalah sebagai berikut:

a) Sosialisasi program pengabdian KKN-PPM untuk menyatukan persepsi tim pengusul dan mitra dalam pelaksanaan program. b) Tim pengabdi beserta mitra melakukan recording pelaku usaha pembuatan ikan kering dengan melibatkan pemerintah setempat seperti kepala kelurahan.

c) Dari hasil recording yang di peroleh masyarakat pelaku usaha pembuatan ikan kering dikelompokan untuk diberikan pembinaan dengan peningkatan pengetahuan dan keterampilan melalui pelatihan, antara lain:

(1) Penguatan jiwa entrepreneurship pada semua peserta

(2) Pelatihan teknis pembuatan ikan kering yang baik dengan menghindari penggunaan bahan-bahan kimia berbahaya melalui introduksi cara pembuatan ikan kering yang sudah di persiapkan tim pengabdi.

(3) Praktik langsung dan melihat hasil dari introduksi yang di berikan tim pengabdi bersama mitra.

(4) Pelatihan manajemen pengolahan ikan dan cara menjaga kualitas ikan dengan baik.

(5) Pelatihan manajemen kandungan nutrisi yang terkandung dalam ikan-ikan yang akan dikeringkan.

(6) Pelatihan manajemen pasca produksi

d) Operasionalisasi yang merupakan tahap penentu keberhasilan dari program KKN-PPM ini.

e) Monitoring dan evaluasi program untuk menjamin keberlanjutan dan pengembangan dari program KKN-PPM ini.

Pelaksanaan kegiatan KKN-PPM ini akan terlaksana dengan baik melalui kerjasama dan partisipasi aktif dari mitra dan peserta. Mitra juga 
berpartisipasi dalam hal penyiapan workshop di lokasi mitra.

\section{HASIL DAN PEMBAHASAN}

\section{Rencana Keberlanjutan Program}

Road map program KKN-PPM KKN-PPM

Pola Pembinaan UMKM Usaha Pengolahan Ikan Kering ini direncanakan untuk bisa ditindaklanjuti pada program kerja tahun yang akan datang dan menjadi usaha binaan UKM Manajemen dan Kewirausahaan Sekolah Tinggi Ilmu Ekonomi Muhammadiyah Palopo, guna memastikan efektivitas dan efisiensi program yang telah dilakukan di tahun sebelumnya, hal ini penting karena pada hakikatnya untuk menjaga kesinambungan dan keberdayaan masyarakat perlu adanya pendampingan yang sifatnya berkelanjutan.

Fungsi keterlibatan mitra dalam hal ini Kelompok Nelayan Tapong Palopo yang merupakan organisasi kemasyarakatan sangat strategis, selain tugas dan fungsi yang melekat pada organisasinya, mitra dalam hal ini telah berkomitmen untuk terus mengembangkan dan menjadikan unit usaha mandiri yang akan bekerjasama dengan masyarakat pedesaan dan memberdayakan pemuda pengangguran yang akan dibina dan direkrut untuk focus bekerja dan mengembangkan hasil program KKN-PPM yang akan diselenggarakan menjadi usaha penuh dan bersifat komersil.

\section{Kelayakan Perguruan Tinggi}

Sekolah Tinggi Ilmu Ekonomi (STIE) Muhammadiyah Palopo merupakan suatu pendidikan tinggi yang aktif dalam melaksanakan program pengabdian masyarakat sebagai salah satu program Tri Dharma Perguruan Tinggi. Kegiatan program pengabdian masyarakat ini dikoordinir dalam satu lembaga yaitu Pusat Penelitian dan Pengabdian pada Mayarakat (P3M) STIE Muhammadiyah Palopo. Lembaga ini telah banyak melakukan program-program pengabdian masyarakat baik berupa fisik maupun non fisik.

Salah satu program pengabdian yang dilakukan adalah Kuliah Kerja Nyata (KKN) setiap tahun dengan mewajibkan kepada seluruh mahasiswa tingkat akhir yang telah memenuhi syarat akademik. Kurikulum STIE Muhammadiyah Palopo memasukkan KKN sebagai mata kuliah wajib dengan 4 SKS pada mahasiswa tingkat akhir.

Tema KKN yang telah dilaksanakan oleh STIE Muhammadiyah Palopo, adalah peningkatan kesejahteraan ekonomi masyarakat pedesaan, dengan KKN. Sesuai dengan latar belakang dan kompetensi keilmuan Sumber daya yang di miliki oleh STIE Muhammadiyah Palopo. Untuk mencapai tujuan KKN yang telah dilakukan, STIE Muhammadiyah Palopo melakukan kerjasama dengan pemerintah daerah, Badan Usaha Milik Negara maupun Daerah, serta pelaku-pelaku usaha yang mempunyai kepentingan dengan masyarakat setempat.

\section{Target}

Target yang hendak dicapai melalui Program Pengabdian KKN-PPM di kelurahan Ponjalae dan kelurahan Tapong ini adalah:

1. Mengedukasi dan Memotivasi masyarakat kelurahan Ponjalae dan Tapong untuk berwirausaha dalam melahirkan produk baru dengan sumber bahan baku yang tersedia 
melimpah karena memiliki bekal keterampilan dan ilmu dalam mengolah dan memanfaatkan ikan yang bernilai ekonomis rendah yang selama ini belum di usahakan secara maksimal dan meberikan nilai ekonomi kepada para nelayan.

2. Terjadi penyerapan tenaga kerja dan pengurangan angka pengangguran di pedesaan sehingga mampu menekan angka urbanisasi.

3. Meningkatkan keberdayaan ekonomi dan kesejahteraan mitra dan masyarakat pedesaan pada umumnya.

4. Publikasi ilmiah hasil yang dicapai oleh masyarakat pesisir dan nelayan guna memberikan inspirasi kepada masyarakat pesisir lainnya khususnya nelayan dalam pemanfaatan hasil tangkapannya.

\section{Luaran}

Indikator keberhasilan Program Pengabdian KKN-PPM Pola Pembinaan UMKM Usaha Pengolahan Ikan Kering Di Kelurahan Ponjalae Tapong Kecamatan Wara Kota Palopo akan menghasilkan luaran berupa:

1. Usaha Mikro kecil dan Menengah (UMKM) Pengolahan Ikan Kering dalam skala Industri kecil yang mampu menopang kebutuhan protein murah di wilayah Luwu Raya dan Sulawesi.

2. Produk Ikan kering berkualitas yang siap menembus pasar local dan Nasional.

3. Publikasi Ilmiah dan Paten

4. Menumbuhkan jiwa entrepreneurship bagi semua peserta.
5. Peningkatan pengetahuan dan keterampilan tentang pemanfaatan dan meningkatkan nilai ekonomis ikan curah hasil tangkapan nelayan.

6. Terjadinya transfer/alih teknologi proses pengolahan ikan bernilai ekonomis rendah menjadi ikan kering.

7. Memberikan manfaat terhadap peningkatan kesejahteraan perekonomian masyarakat secara permanen dan berkelanjutan.

\section{DAFTAR PUSTAKA}

Anderson, P, 1982. Commercial Fisheries Under Price Uncertainty. Journal of Environmental Economics and Management, 9 (1):11-28.

Asriani, Putri Suci, 2007. Kajian Sistem Agribisnis Perikanan Tangkap di Provinsi Bengkulu. Tugas Kuliah TS Manajemen Agribisnis Program S3 Ekonomi Pertanian FP Universitas Gadjah Mada. Yogyakarta.

Downey, W. David dan Erickson, Steven P., 1988. Manajemen Agribisnis; edisi terjemahan. Penerbit Erlangga. Jakarta

Hanafiah, A.M. dan Saefuddin, A.M., 1978. Tataniaga Hasil Perikanan. Penerbit Universitas Indonesia (UI Press). Jakarta.

Huseini, Martani, 2007. Masalah dan Kebijakan Peningkatan Produk Perikanan untuk Pemenuhan Gizi Masyarakat: Makalah Seminar Nasional Hari Pangan Sedunia. Dirjen Pengolahan dan Pemasaran Hasil Perikanan Departemen Kelautan dan Perikanan RI. Jakarta.

Koonsee, Brett, 2007. Hasil Survei FDA: Produk Perikanan Penuhi Standar. Surya Online. http://www.surya.co.id/web.

Latuconsina, Husain, 2007. Antara Peningkatan Devisa dan Gemar Ikan. Manajemen Sumberdaya Perikanan Universitas Darussalam. Ambon.

Suara Pembaharuan,2006. UE Beri Kesempatan Perbaiki Kualitas Produk Perikanan. SP Online. http://www.sp-online.com. 